\title{
高加工性 $\mathrm{Cu}-\mathrm{Al}-\mathrm{Mn}$ 基 形状記憶合金の開発
}

\author{
須藤祐司* 大森俊洋** \\ 石田清仁**** 山内 清*****
}

\section{1. は じめに}

形状記憶合金は, 形状記憶効果以外にも可逆 (2 方向)形状 記憶効果, 超弾性効果, 制振特性などといった付随する優れ た機能を有するため, 古くから多くの研究が行われている. 今まで実用に供された形状記憶合金としては， Ni-Ti 基合金， $\mathrm{Cu}-\mathrm{Zn}-\mathrm{Al}$ 基合金, $\mathrm{Fe}-\mathrm{Mn}-\mathrm{Si}$ 基合金などが挙げられるが， 形状記憶特性や種々の材料特性に関して極優れているた め, $\mathrm{Ni}-\mathrm{Ti}$ 基合金が実用材の殆どを占めており， Ni- $\mathrm{Ti}$ 基合 金が形状記憶の代名詞上さ元言える状況にある。しかし， $\mathrm{Ni}-\mathrm{Ti}$ 基合金も冷間加工性が不十分であり，素材や製造コス 卜が比較的高くつくことなど，いくつか欠点を持っている. 一方, $\mathrm{Cu}$ 系形状記憶合金は，素材的に低コストが期待され ることから歴史的に多くの研究がされてきたが，加工性にそ しいことが最後まで問題とされてきた。加工性の改善には結 晶粒微細化が有効とされ，Ti や B などの添加元素による結 晶粒微細化が図られたが，加工性も形状記憶特性も今なお十 分なレベルには至っていない(1)(2).

著者らは, 近年 $\mathrm{Cu}-\mathrm{Al}$ 合金に $10 \mathrm{at} \%$ 以上の $\mathrm{Mn}$ を添加し た 3 元合金が，優れた加工性と形状記憶特性を示すことを 見出し，組織制御を駆使することにより $\mathrm{Ni}$ - $\mathrm{Ti}$ 基合金に匹 敵するほどの優れた形状記憶特性が得られることを報告し た(3)-(11). 本報は， $\mathrm{Cu}-\mathrm{Al}-\mathrm{Mn}$ 合金の全体像と組織制御に関 する概略を述べ，実用への試みについて紹介する.

\section{2. 状態図と機械特性}

図 1(a)拈よび(b) は， $800^{\circ} \mathrm{C}$ に㧍ける $\mathrm{Cu}-\mathrm{Al}-\mathrm{Mn}$ 系の等温 断面㘠扝上び $\mathrm{Cu}-\mathrm{Al}-10$ at \% Mn の縦断面状態図を示してい る(12). $\beta$ 単相領域は, Mnの添加により特に低 $\mathrm{Al}$ 濃度側に 大きく拡大することがわかる。また，図1(b)に見られるよ うに, $\mathrm{Cu}-\mathrm{Al} 2$ 元系では高温域の久に存在していた $\beta$ 単相領 域が， $400^{\circ} \mathrm{C}$ 以下の低温域でも安定になり, 高温から不規則 $\mathrm{A} 2 \sim$ 規則 B2 規則 L 2 ホイイスラー相への逐次規則一不規則 変態が出現する. $\mathrm{A} 2 / \mathrm{B} 2$ および $\mathrm{B} 2 / \mathrm{L} 2_{1}$ 規則化温度は, $\mathrm{Al}$ 濃度に敏感であり, $\mathrm{Al}$ 濃度が $18 \%$ 以下になると共に $500^{\circ} \mathrm{C}$ を下回る。このような規則変態温度の低下は, 必然的に L $2_{1}$ 相の規則度の低下を伴うと予想される。実際，約 16 at \% Al を境にして，高 $\mathrm{Al}$ 側では水燒入れしても $\mathrm{L} 2$ 規則化を阻止 できないが，16 at\% A1 以下の組成では焼入れにより不規則 $\mathrm{A} 2$ 構造が凍結される. L $21_{1}$ 相抢よび $\mathrm{A} 2$ 相から生じるマル テンサイトは, それぞれ $6 \mathrm{M}$ 長周期積層構造と $\mathrm{fcc}-\mathrm{A} 1$ 構造 であることがわかっている(4).

図 2 は, $\mathrm{Cu}-\mathrm{Al}-\mathrm{Mn} \beta$ 単相合金の冷間加工性, 引張破断伸 び，形状記憶特性について $\mathrm{Al}$ 濃度の影響を示したものであ る.ここで，冷間加工性は，途中焼鈍せずにクラックが出現 する直前まで冷間圧延した場合の最大压下率と定義してい る. また, 形状記憶特性は, 液体窒素温度で約 $0.2 \mathrm{~mm}$ 厚の 板材に表面䄳で $2 \%$ の曲げ变形を加光, $200^{\circ} \mathrm{C}$ まで加熱した 場合の回復率を示している. 図からわかるように, 冷間加工

$*$ 東北大学大学院工学研究科材料物性学専攻 : 日本学術振興会特別研究員

** 東北大学大学院生; 大学院工学研究科材料物性学専攻

*** 東北大学助教授; 大学院工学研究科材料物性学専攻 (厂980-8579 仙台市青葉区青葉山02)

**** 東北大学教授; 大学院工学研究科材料物性学専攻

***** NEC トーキン株式会社技師長

Development of Cu-Al-Mn-based Shape Memory Alloys with Enhanced Ductility; Yuji Sutou*, Toshihiro Omori**, Ryosuke Kainuma $^{* * *}$, Kiyohito Ishida****, Kiyoshi Yamauchi***** (*-*****)Department of Materials Science, Graduate School of Engineering, Tohoku University, Sendai. *****NEC TOKIN Co., Sendai)

Keywords: Cu-based shape memory alloy, texture, grain size, martensitic transformation, microstructural control, guidewire 2003 年 9 月 5 日受理 
性, 引張破断伸び，形状記憶特性のいずれたついても $9 \mathrm{Mn}$ 〜13Mn の範团内では Mn 濃度にあまり依存していない。一 方, $\mathrm{Al}$ 濃度には大きく依存し, 特に冷間加工性は $\mathrm{Al}$ 濃度が 21 at\%以下の領域から急激に上昇し，不規則構造となる 16

(a)

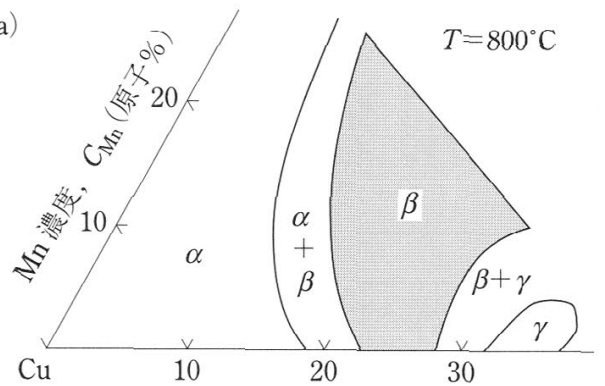

$\mathrm{Al}$ 濃度, $C_{\mathrm{Al}}$ (原子\%)

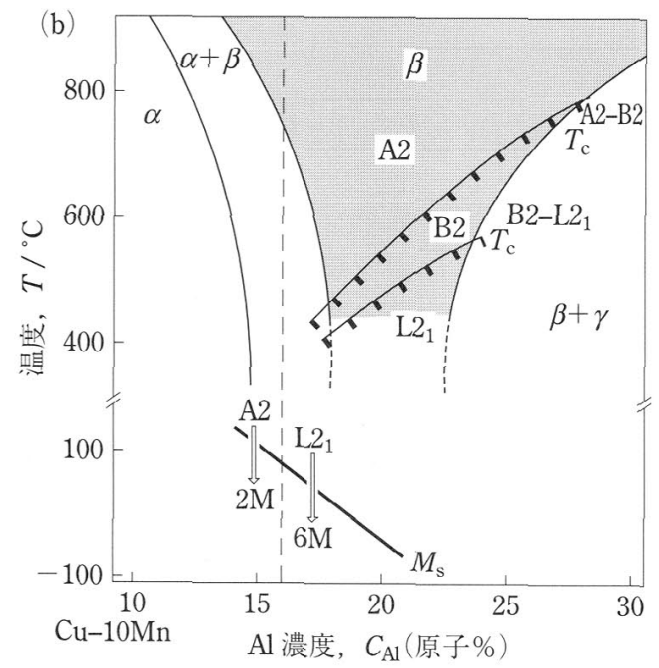

図 $1800^{\circ} \mathrm{C}$ における $\mathrm{Cu}-\mathrm{Al}-\mathrm{Mn}$ 系状態図上(b) $\mathrm{Cu}-$ $\mathrm{Al}-10$ at\% $\mathrm{Mn} の$ 縦断面状態図.

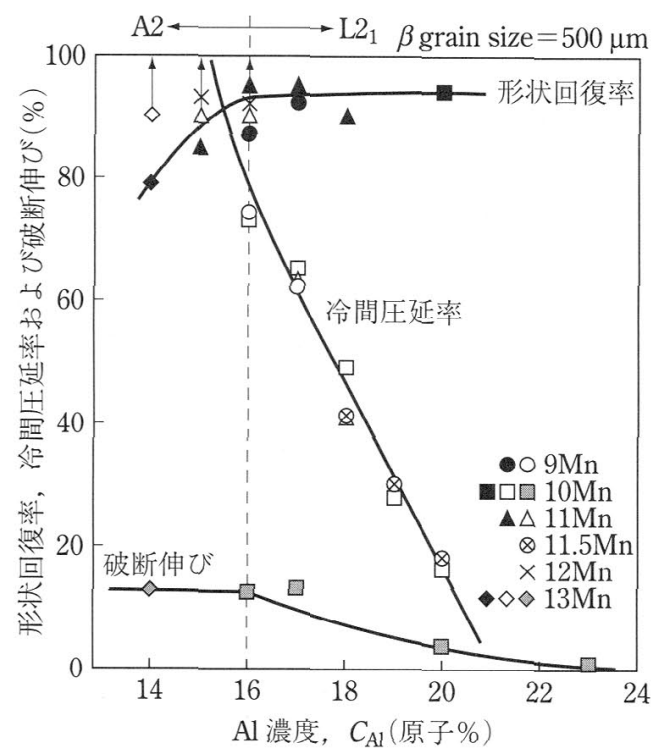

注 $2 \mathrm{Cu}-\mathrm{Al}-(9-13) \mathrm{at} \% \mathrm{Mn} \beta$ 単相試料の形状回復率, 冷間加工性および破断伸び. at $\%$ に至っては $80 \%$ 程度の冷間加工性が得られる。 Ti-Ni 合 金や $\mathrm{Cu}-\mathrm{Zn}-\mathrm{Al}$ 合金では，同様の手法により評価される冷間 加工率は高々 $20 \sim 30 \%$ 止まりであることから，形状記憶効 果もさほど低下せず良好な加工性㧍よご機械特性が得られる $17 \sim 18 \% \mathrm{Al}$ 合金が，新しいタイプの高加工性 $\mathrm{Cu}$ 基合金の 候補として有望であることが見出された。

\section{3. マルテンサイト変態温度と形状記憶特性}

$\mathrm{Cu}-\mathrm{Al}-\mathrm{Mn}$ 合金のマルテンサイト変態温度は, 以前から 報告があり(13)-(16)，マルテンサイト変態開始 $\left(M_{\mathrm{S}}\right)$ 温度につ いては，Al 抢よび $\mathrm{Mn}$ 濃度との関係で次式が提案されてい る。

$$
M_{\mathrm{S}}\left({ }^{\circ} \mathrm{C}\right)=1856-63.2[\text { at } \% \mathrm{Al}]-63.9[\text { at } \% \mathrm{Mn}]
$$

しかしながら, 以前の研究で対象とされた合金の Mn 濃 度は㧍招むね 5 at $\%$ 以下であり, 規則度の高い 20 at $\% \mathrm{Al}$ 以 上の合金に限られていた。著者らは，丹相 L $2{ }_{1}$ 相の規則度 が著しく低下する 20 at\%以下の $\mathrm{Al}$ 濃度領域の合金について 詳細に調査したところ, 図 $3(\mathrm{a})$ に示すように合金の $M_{\mathrm{s}}$ 温度

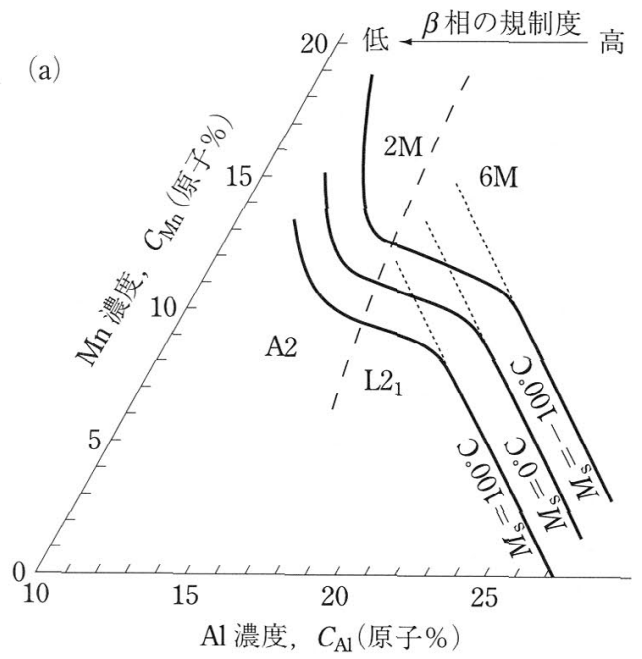

(b)

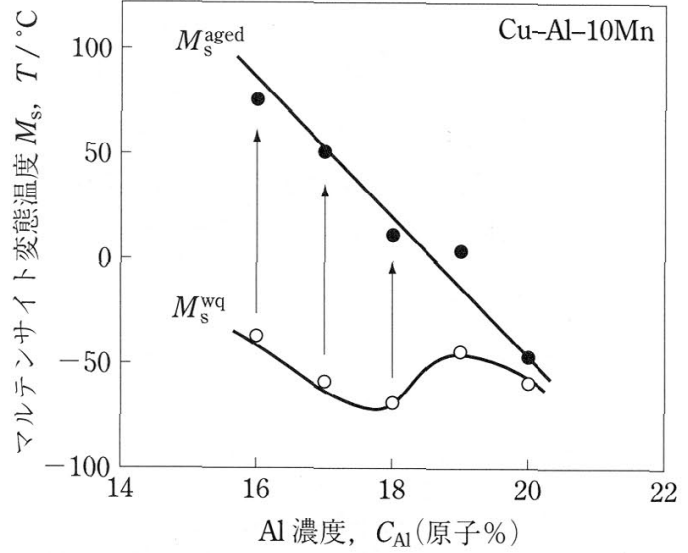

図 $3 \mathrm{Cu}-\mathrm{A} 1-\mathrm{Mn} \beta$ 単相試料に扔け万等 $M_{\mathrm{s}}$ 線図々 ( b ) $\mathrm{Cu}-\mathrm{Al}-10 \mathrm{Mn}$ 合金に抢ける焼入材㧍よび $150^{\circ} \mathrm{C}$ (15分) 時効材の $M_{\mathrm{s}}$ 温度. 

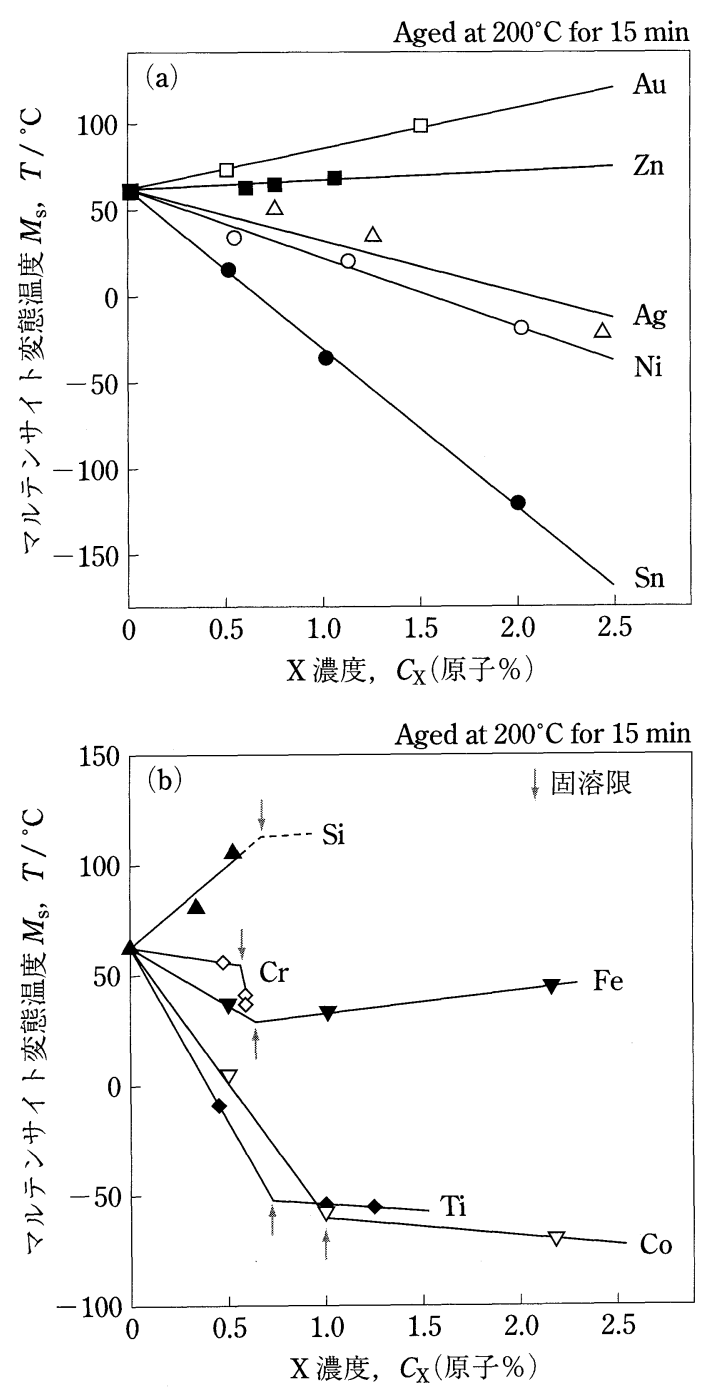

図 $4 \mathrm{Cu}-\mathrm{Al}-\mathrm{Mn} \beta$ 単相試料における $M_{\mathrm{s}}$ 温度の添加元 素依存性.（a）完全固溶タイプ，（b）部分固溶タ イプ.

は, 式 (1)の関係から大きく偏倚することを見出した. 図 3 (b) は, $10 \% \mathrm{Mn}$ 合金に打ける $M_{\mathrm{s}}$ 温度の $\mathrm{Al}$ 濃度依存性を 示している. $16 \% \mathrm{Al}$ 周辺では $150^{\circ} \mathrm{C}$ 時効による $M_{\mathrm{s}}$ 温度の上 昇は顕著であり， $M_{\mathrm{s}}$ 温度は約 $100^{\circ} \mathrm{C}$ も昇することがわか る。電子顕微鏡を用いた解析により，16\% $\mathrm{Al}$ 合金の母相は 低温時効により $\mathrm{A} 2$ から規則 $\mathrm{L} 2{ }_{1}$ 相へと変化し，それ以外の 規則合金でも規則度が上昇する傾向が確認された.このこと より，図3(a)に見られた式（1）からの偏倚は, 母相の規則 度の低下に起因すると考えられる。

$M_{\mathrm{s}}$ 温度に及ぼす $\mathrm{Ti}, \mathrm{Cr}, \mathrm{Fe}, \mathrm{Co}, \mathrm{Ni}, \mathrm{Ag}, \mathrm{Au}, \mathrm{Zn}, \mathrm{Si}, \mathrm{Sn}$ 等の微量添加元素の影響について調査するため, 母合金 $\mathrm{Cu}_{73} \mathrm{Al}_{17} \mathrm{Mn}_{10}$ に対し分鋳法を用いて $2 \%$ 程度までの合金元素 を数回に分けて添加した試料を作製した。すなわち， $\left(\mathrm{Cu}_{73} \mathrm{Al}_{17} \mathrm{Mn}_{10}\right)_{100-x}-\mathrm{X}_{x}(x: 0-2.0)$ で示される組成の合金を 用意した ${ }^{(5)}$. 図 $4(\mathrm{a})$ および (b)にDSCで測定した $M_{\mathrm{s}}$ 温度 の結果を示す。ここで, 合金は全て $900^{\circ} \mathrm{C}$ から焼入れした後, $200^{\circ} \mathrm{C}-15 \min$ の安定化処理を施行している. 図からわかる

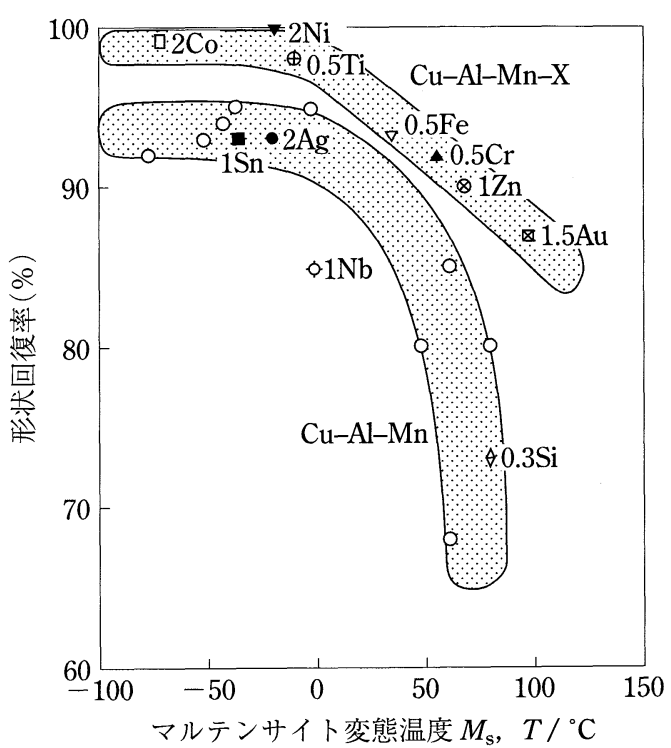

図 5 曲げ試験による形状回復率の $M_{\mathrm{s}}$ 温度依存性.こ こで, 変形は液体窒素温度で, 形状回復は $200^{\circ} \mathrm{C}$ への加熱後に評価した.

ように, $\mathrm{Zn}, \mathrm{Au}, \mathrm{Si}$ を除く全ての元素は $M_{\mathrm{s}}$ 温度を低下させ ている，一方， Si は著しく $M_{\mathrm{s}}$ 温度を上昇させることがわか る.これらの添加元素と $M_{\mathrm{s}}$ との関係は, 次式によって示さ れる.

$$
\begin{aligned}
M_{\mathrm{s}}\left({ }^{\circ} \mathrm{C}\right)= & 62-40[\mathrm{at} \% \mathrm{Ni}]+5[\mathrm{at} \% \mathrm{Zn}]-30[\mathrm{at} \% \mathrm{Ag}] \\
& -92[\mathrm{at} \% \mathrm{Sn}]+23[\mathrm{at} \% \mathrm{Au}]-143[\mathrm{at} \% \mathrm{Ti}] \\
& -4[\mathrm{at} \% \mathrm{Cr}]-41[\mathrm{at} \% \mathrm{Fe}]-117[\mathrm{at} \% \mathrm{Co}] \\
& +74[\mathrm{at} \% \mathrm{Si}]
\end{aligned}
$$

ここで，アンダーラインを付した元素は, 図 4(b)に示す ように $0.5 \%$ 程度までしか固溶しない.

図 5 に合金の $M_{\mathrm{s}}$ 温度と形状記憶特性の関係を示してい る.ここで, 形状記憶特性は, 前述した曲げ試験(液体窒素 温度で $2 \%$ の表面歪みを印加後, $200^{\circ} \mathrm{C}$ に加熱)による簡便な 手法で評価した．図に示すように，3元系より4元系合金の 方が特性は良好であり, $M_{\mathrm{s}}$ 温度が $0^{\circ} \mathrm{C}$ 以上では, $M_{\mathrm{s}}$ 温度が 高いほど特性の低下が著しい，この形状記憶特性の低下は,

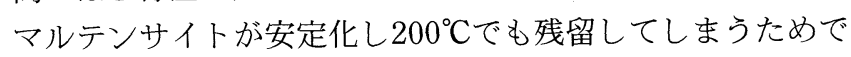
あるが，その原因は明らかにマルテンサイト変態時における 転位の導入であると考えられる. 添加元素により特性向上が 得られたのは, Co, Ni, Ti 等の添加元素が固溶強化や析出強 化に寄与して転位の導入を抑制すためであると説明できる.

\section{4. 超 弾 性}

\section{（1）結晶粒径による特性制御}

$\mathrm{Cu}$ 系形状記憶合金においては，その形状記憶特性が結晶 粒径 (平均直径) $d$ もしくは板厚 $t$ で規格化した比粒径 $d / t$ に 依存し， $d$ や $d / t$ が大きいほど良好な特性を示すことは古く から知られていた ${ }^{(17)(18)}$. しかし, 既存の $\mathrm{Cu}-\mathrm{Al}-\mathrm{Ni}$ や $\mathrm{Cu}-$ $\mathrm{Zn}-\mathrm{Al}$ 合金では, 結晶粒を粗大化させると粒界破壊や疲労破 
壊が顕著になるために $2 \%$ 程度の限られた変形歪みしか与え ることは出来ない，塑性変形能と形状記憶特性が結晶粒径に 関してトレード・オフの関係になっているため, 粒径を用い た形状記憶特性の制御には大きな制約が存在しているのであ る.一方, $\mathrm{Cu}-\mathrm{Al}-\mathrm{Mn}$ 合金では, 図 2 に示したように比較 的低い $\mathrm{Al}$ 濃度を有する合金においては高い延性を示すた め, 加工熱処理によって得られる種々の粒径範囲で形状記憶 特性を調査することが出来た.

図 6 は, 様々な結晶粒径のワイヤーを用いて行った引張サ イクル試験の結果を示している(4)(5)。ここで, 歪み速度は $0.5 \mathrm{~mm} / \mathrm{min}$ ，ゲージ長は $50 \mathrm{~mm}$ の条件で測定した。いず れも逆変態終了温度 $A_{\mathrm{f}}$ より $30^{\circ} \mathrm{C}$ 高い温度で行ったもので, 超弾性特性が見られる.ここでは, 粒径のかわりに比粒径 $d / D$ (粒径をりイヤ一直径 $D$ で割った值)を用いているが, 比粒径が 1 よりも大きい場合には図 6(a)のように単結晶に 近い特性が得られ，1よりかなり小さい場合には図 6 (c) の ように超弾性の特性が著しく劣化することがわかった。これ らの応力-歪及線図から $i$ サイクル目の賞味の超弾性歪及 $\varepsilon_{\mathrm{SE}}^{i}$ と見かけ上の塑性変形歪み $\varepsilon_{\mathrm{t}}^{i}-\varepsilon_{\mathrm{e}}^{i}$ との関係をプロットしたの

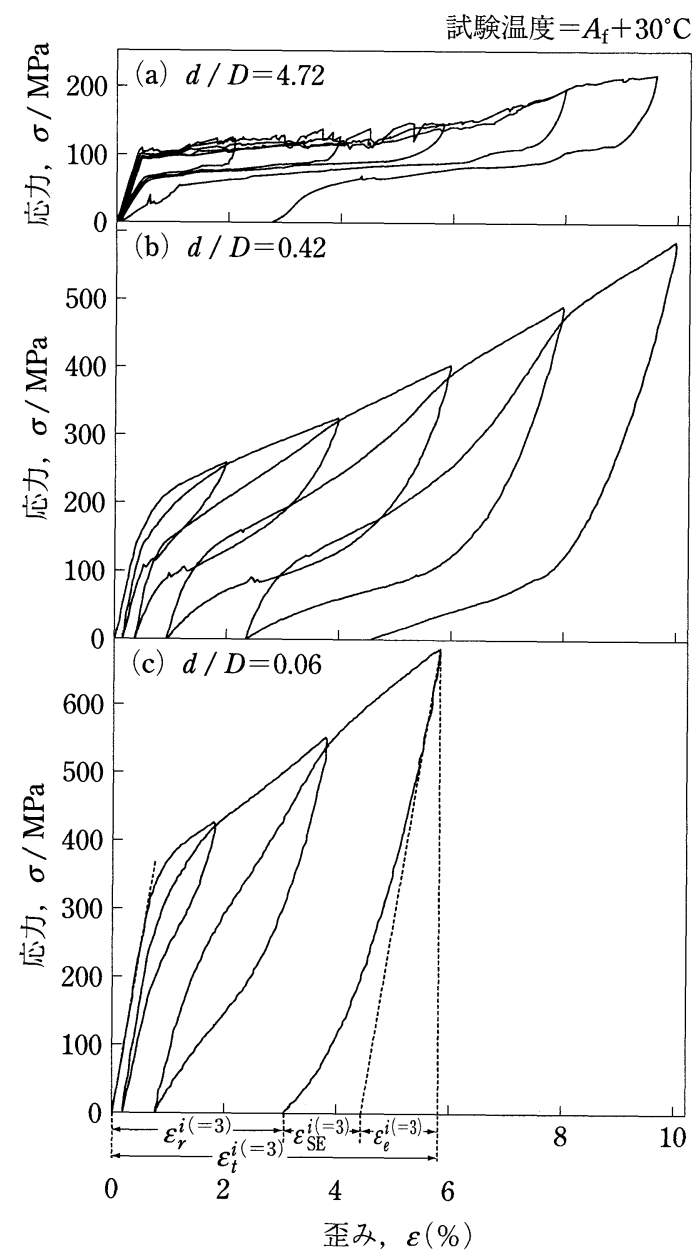

図 6 超弾性合金の応力-雪みサイクル線図.ここで, 各試料の比粒径は (a) $d / D=4.72$, (b) $d / D=0.42$ および (c) $d / D=0.06$ であり, 試験温度は $A_{\mathrm{f}}+$ $30^{\circ} \mathrm{C}$ とした.
が図 7 である.ここで, $\varepsilon_{\mathrm{SE}}^{i}=\varepsilon_{\mathrm{t}}^{i}-\varepsilon_{\mathrm{e}}^{i}$ の関係を示す破線上にプ ロットが乗れば，完全な超弾性であることを意味している. 図からわかるように, 比粒径が大きいほど, 大きな超弾性歪 みが得られる事がわかる. 特に $d / D=4.72$ は, $\mathrm{Cu}$ 系では今 までに報告が無い $7 \%$ 以上の形状回復が得られる。ちなみ に,この試料は完全に竹節組織 (bamboo structure)を呈して いる. 図 7 に示されているような定義によって得られた最 大超弾性歪み $\varepsilon_{\mathrm{SE}}^{\mathrm{MAX}}$ を比粒径で対数プロットしたのが図 8 で ある.このプロットから, 本超弾性合金は比粒径に関して 3 つの領域に分類できることがわかる．まず，ほぼ $d / D<0.2$ に対応する領域 I では, 最大超弾性丕みは $2 \%$ 以下であり, 微細結晶粒を有する他の $\mathrm{Cu}$ 系形状記憶合金で報告されてい る性能に対応している. 次に $d / D>1.0$ に対応する領域正で は, 最大超弾性歪みはいずれも $6 \%$ を越えている. また, 領 域 II は, 領域 I とIII遷移領域にあると見られ, 比粒径に大 きく依存している. 領域 I で殆ど定常的に特性が低いのは, この領域では各結晶粒が 3 次元的に周辺の結晶粒から拘束 を受けるからであり, 領域 II からII で特性が向上するのは, この領域では試料表面に面する結晶粒の割合が増加して, 周

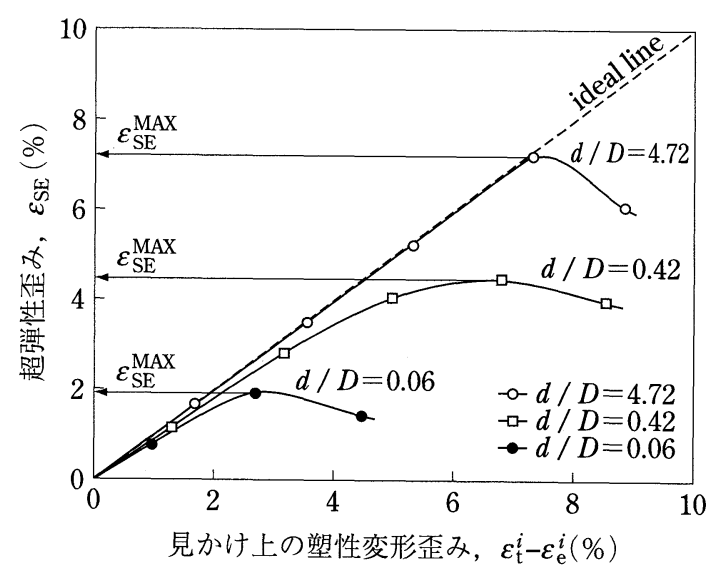

図 7 見かけ上の塑性変形歪み $\varepsilon_{\mathrm{t}}^{i}-\varepsilon_{\mathrm{e}}^{i}$ に対する超弾性歪 み $\varepsilon_{\mathrm{SE}}^{i}$ のプロット.

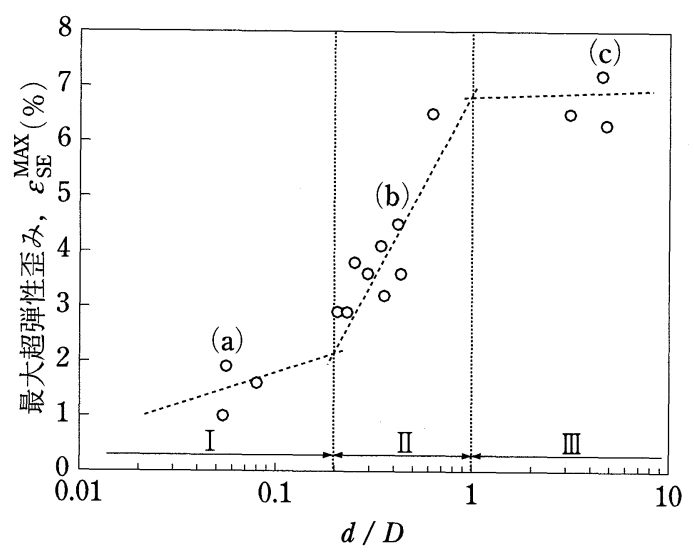

図 8 比粒径 $d / D$ に対する最大超弾性歪み $\varepsilon_{\mathrm{SE}}^{\mathrm{MAX}}$ のプロ ット. 
りからの拘束が減少するからであると説明できる。実際に超 弾性特性がきわめて良好になるのは，ちょうど組織が竹節状 になると予想される $d / D=1.0$ 以上である( ${ }^{(9)}$. 竹節状組織の リイヤーを曲げると不自然な折狆曲がりが出るため, 実用的 には $d / D>1.0$ と吋るとはなるべく避け， $0.2<d / D<1.0$ の領域をうまく利用する必要が有ると考えられる.

\section{（2）集合組織による特性制御}

集合組織は，形状記憶特性を向上させるために最も有効な 千法の一つである。集合組織を得るためには，加工熱処理 法 (19)-(21)，急冷凝固法(21) (22)， スパッ夕法(23) 等の手法があ るが，バルク材料に対し実用的に最も利用しやすいのが加工 熱妈理であり，実際に Ni-Ti 基合金では集合組織が広く利 用されている，先にも述べたように，従来の $\mathrm{Cu}$ 基合金は加 工性に乏しく，集合組織を得るに十分な加工ができないた め, 加工熱処理による集合組織の利用は殆ど報告されていな い，そこで，加工性に富む $\mathrm{Cu}-\mathrm{Al}-\mathrm{Mn}$ 基合金を利用して, 加工熱処理による集合組織の形成を試みその形状記憶特性へ の影響を調査した。

図 9 は, fcc $(\alpha$ 相 $)+\operatorname{bcc}(\beta$ 相) の 2 相状態で約 $88 \%$ 冷間加 工した後に $950^{\circ} \mathrm{C}$ で溶体化した $\left(\mathrm{Cu}_{73.5} \mathrm{Al}_{17} \mathrm{Mn}_{9.5}\right)_{97}-\mathrm{Ni}_{3}$ 試料 について，SEM-EBSD 法を用いて得られた(100)正極点図 である (7)(9). 図から，この試料は $\{112\}\langle 110\rangle,\{111\}\langle 112\rangle$ および $\{001\}\langle 110>03$ 種の集合組織が混在しているが，特 に $\{112\}\langle 110\rangle$ が非常に強力に発達していることがわかる.

この集合組織は，Cu-Al-Mn 3 元系ではさほど強力に形成さ れないが，Ni を添加した場合に顕著であった ${ }^{(7)}$. Ni 添加で

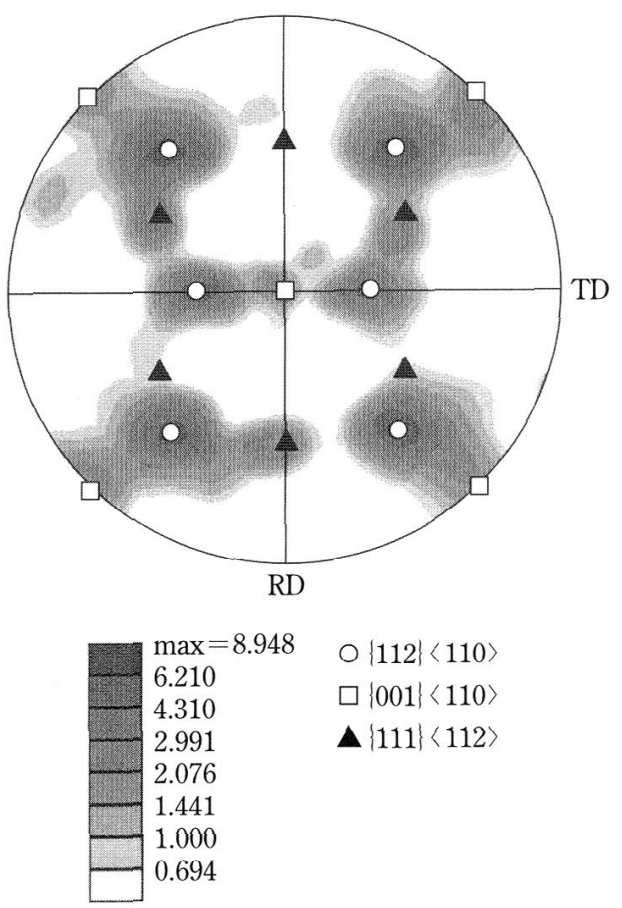

図 $988 \%$ の冷間压延後 $950^{\circ} \mathrm{C}$ (5 分)の溶体化を行った $\left(\mathrm{Cu}_{73.5} \mathrm{Al}_{17} \mathrm{Mn}_{9.5}\right)_{97}-\mathrm{Ni}_{3}$ 板試料の (100) 正極点 図. 強い $\{112\}\langle 110\rangle$ 集合組織を示す.
集合組織が発達した理由としては，Ni 添加により加工暁鈍 時の $\alpha$ 相の分率が高まり, 組織が微細化していたことが関 与していると考えられる。すなおち，(1) $\alpha$ 相の分率が高い ので 3 元系より冷間加工率を高めることが山来たこと, (2) $\alpha$ 相がマトリックスになっている状態で, しかも組織が非常に 微細だったため $\beta$ 相に集合組織が形成され易い，なよ゙とい った理由が考えられる。

図 9 のような強力な $\{112\}\langle 110\rangle$ 集合組織が存在するとす れば，そこから異なる力向に試料を切り出せ价，超弾性特性 は大きく異なるはずである，そこで，冷間圧延加工時の圧延 方向 $(\mathrm{RD})$, 幅方向 (TD)そしてその中間方向 (45 from RD)
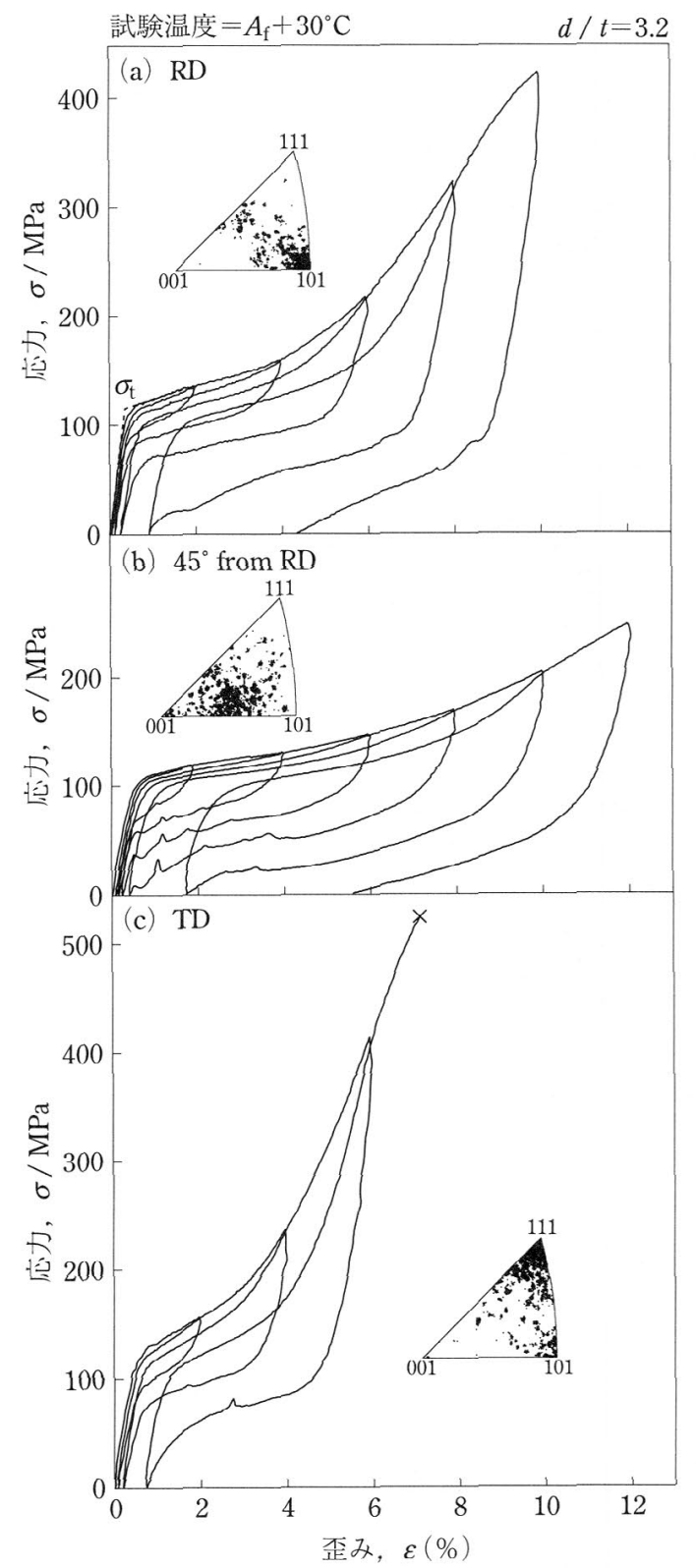

図10 集合組織を持った $\left(\mathrm{Cu}_{73.5} \mathrm{Al}_{17} \mathrm{Mn}_{9.5}\right)_{97}-\mathrm{Ni}_{3}$ 試料の 応力一歪及サイクル線図. ここで, 各試料の引張 試験方位は（a）RD：圧延方向，（b） $45^{\circ}$ from $\mathrm{RD}$ ：RD と TDの中間方向および (c) TD : 幅方 向であり, 試験温度は $A_{\mathrm{f}}+30^{\circ} \mathrm{C}$ した。 


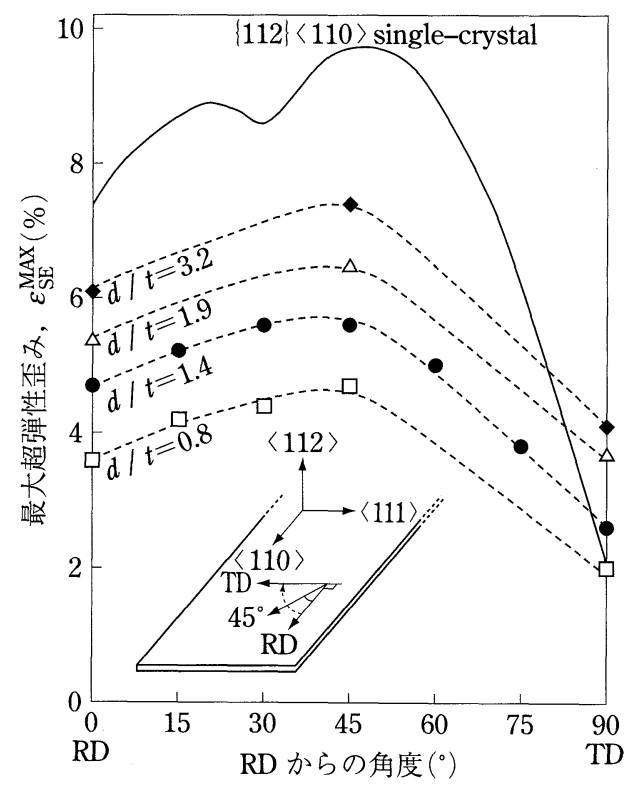

図11 異なる比粒径を有する集合組織 $\left(\mathrm{Cu}_{73.5} \mathrm{Al}_{17.5} \mathrm{Mn}_{9.0}\right)_{97}$ $\mathrm{Ni}_{3}$ 試料の最大超弾性歪及 $\varepsilon_{\mathrm{SE}}^{\mathrm{MAX}}$ の試験方位依存性. $\{112\}\langle 110\rangle$ 方位の単結晶について現象論から計算さ れた值も比較として示す.

の代表的な 3 方向を引張軸とするように切り出して試験を 行った結果が図10である。ここで，試料サイズは， $20 \mathrm{~mm}$ $\times 4.5 \mathrm{~mm} \times 0.25 \mathrm{~mm}$ ，試料厚みを $t$ とした場合の比粒径が $d / t=3.2$ の柱状晶組織試料を用いた。図中には，それぞれの 引張軸方向における集合組織の逆極点図と応力一歪み線図を 示している(7).ここに示すように, 引張方位の違いにより, 超弾性曲線は大きく異なり, 応力誘起変態の臨界応力 $\sigma_{\mathrm{t}}$ p 最大超弾性歪みにも違いが見られた，図11は，圧延方向から 幅方向へ少しずつ方位を変えながら切り出した場合の最大超 弾性歪みを示している，超弾性歪みは， RD から $45^{\circ}$ までの 間で増加し，そこから TD までは減少する連続的な変化を 示した． 単結晶の最大超弾性丕みは，母相とマルテンサイト 相の格子対応で決められるが，集合組織における方位依存性 は，図11に示す単結晶の計算により予測される結果 ${ }^{(7)}$ と良 い対応を示している。一方，集合組織を持たせながら比粒径 を変化させた場合には，その切出方位による依存性は殆ど変 化せず，図に示すように互いに平行移動した関係が得られ た．以上のように，粒径と集合組織を制御することにより， 板材において $7 \%$ 以上もの大きな超弾性歪みを得ることが可 能である.

線材においても冷間線引加工した場合，図12に示すような

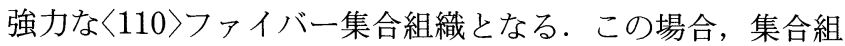
織を持つ試料の超弾性特性は, 集合組織を持たない試料と殆 ぞ同程度の回復特性しか示さなかった (24)。小野らは Taylor モデルを用いて， $\mathrm{Cu}-\mathrm{Al}-\mathrm{Mn}$ と類似した構造を持つ $\mathrm{Cu}-\mathrm{Zn}-$ $\mathrm{Al}$ 合金の〈110〉ファイバー集合組織の回復歪み量を予測し， ランダム組織よりむしろファイバー組織の方が回復歪みは減 少することを報告している(25)、本実験結果は，この予測に

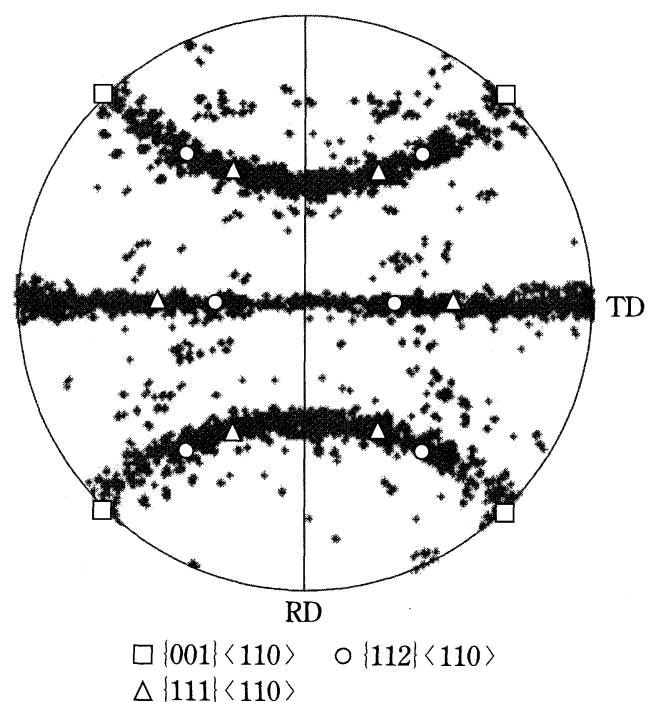

図12 約 $77 \%$ の冷間引抜加工を行った後, $900^{\circ} \mathrm{C} て ゙$ 溶体 化した $\left(\mathrm{Cu}_{73} \mathrm{Al}_{17} \mathrm{Mn}_{10}\right)_{97.8}-\mathrm{Ni}_{2} \mathrm{~B}_{0.2}$ ワイヤー試料 の)(100) 正極点図.

対し定性的に一致する．このように板材と線材で同じ〈110〉 方向の集合組織が異なる傾向を示したのは，板材では压延方 向ばかりでなく板幅や法線方向も方位がそろっているのに対 し, 線材の引張軸以外の方向では結晶方位が完全にランダム であり, 応力印加時における結晶粒間の拘束は依然大きく働 くためであると考えられる.

\section{5. 時効によるベイナイト変態}

$\mathrm{Cu}-\mathrm{Al}-\mathrm{Mn}$ 基合金は，上記形状記憶特性の他に， $300^{\circ} \mathrm{C} \sim$ $400^{\circ} \mathrm{C}$ 程度の温度にて時効することにより著しく硬化する. 図13(a)は, $\mathrm{Cu}_{71} \mathrm{Al}_{18} \mathrm{Mn}_{11}$ 合金のマイクロビッカース硬度に 及ぼす時効温度の影響を示している。ここで, 試料は, $900^{\circ} \mathrm{C}-15 \min$ の溶体化処理後, 各温度にて 15 分間時効し た. 時効温度の上昇に伴い, 硬さは約 $250^{\circ} \mathrm{C} の 280 \mathrm{HV}$ 程度 加ら急激に上昇し, $300^{\circ} \mathrm{C}$ 付近にて約 $390 \mathrm{HV}$ の最大值に達 した後, 低下している. 図13(b)-(d)は, $200,300,350^{\circ} \mathrm{C}$ 各 温度で時効した後の組織を示している. $200^{\circ} \mathrm{C}$ 時効試料は $\beta$ 単相であるが, $300^{\circ} \mathrm{C}$ 以上の温度では, $\beta$ マトリクス中に微 細な板状析出物が観察され，そのサイズは温度の上昇に伴い 大きくなる.X 線回折およびTEM 観察より，この板状析出 物は, 規則 B2 相より生成するマルテンサイトと等価な長周 期積層 (9R) 構造を有していることがわかった ${ }^{(24)}$ 。また, TEM-EDX 分析より板状析出物とマトリクスの組成が異な ることから，この変態には拡散が伴っていることも確認され た. さらに, この板状析出物は, 長時間の時効により, $9 \mathrm{R}$ 構造から積層欠陥の消減した $\alpha$ 相 (不規則 fcc 構造)へと変化 する. 以上のことから時効により生成した板状析出物は, べ イナイト変態により生成した板状ベイナイトであると結論で きる．このようなべイナイト変態は， $\mathrm{Cu}-\mathrm{Zn}-\mathrm{Al}$ 合金等でも 観察されている(26)(27)。 また, $\mathrm{X}$ 線回折より, 時効に伴う $\beta$ 

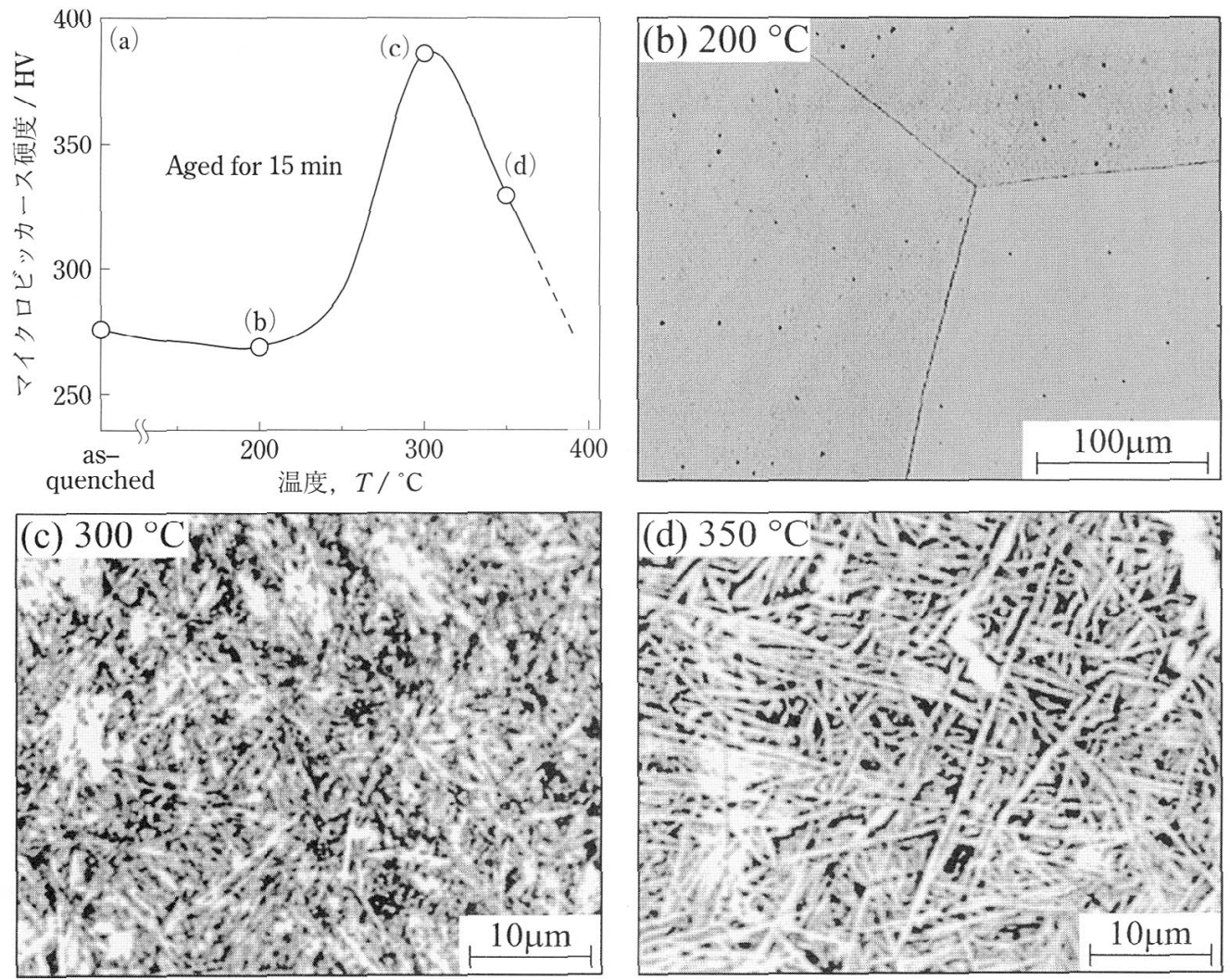

図13＼cjkstart時効温度とマイクロビッカース硬度，および

(b) 200, (c) 300, (d) $350^{\circ} \mathrm{C}$ 各時効試料の顕微鏡組織.

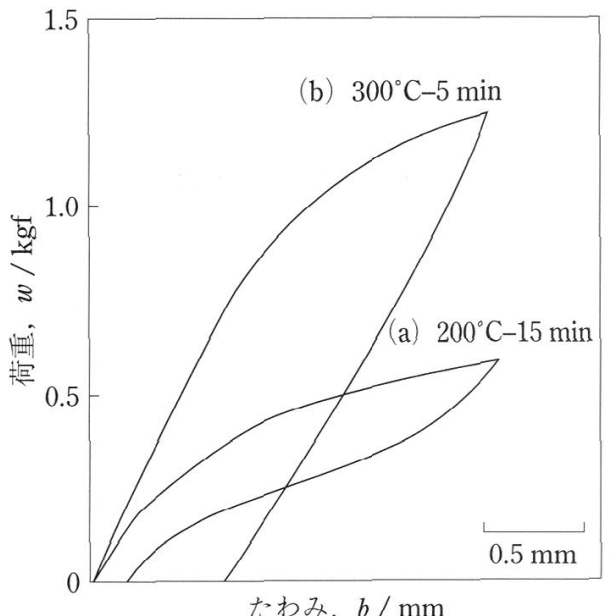

図14 超弾性材 (a) と時効材 (b) の曲げ荷重一たわ六特性.

マトリクスの規則度の上昇も観察された。従って, 時効に伴 う硬さの上昇は, 微細な板状べイナイトを含んた緻密な組織 の形成抢よび $\beta$ マトリクスの規則度の上昇により生じると 考えられる。

図14は，3 点曲げ試験により得られた (a) $200^{\circ} \mathrm{C}$ 時効材およ び(b) $300^{\circ} \mathrm{C}$ 時效材における荷重一たわ久線図を示している. ここで，試験は室温にて，歪み速度 $2 \mathrm{~mm} / \mathrm{min}$ で行われた。 $200^{\circ} \mathrm{C}$ 時効材は，超弾性特性を示し非常に柔軟であるのに対 し， $300^{\circ} \mathrm{C}$ 時效材は，高い剛性抢よび強度を有していること
がわかる，このように， $\mathrm{Cu}-\mathrm{Al}-\mathrm{Mn}$ 基合金では，時効温度 を変化させることにより，機械的特性を大きく恋化させるこ とが出米る.

\section{6. 応用例}

（1）医療用ガイドワイヤーの試作

医療用ガイドワイヤーは，心筋梗塞などに対し，太ももの 大静脈からカテーテルを扦入する医療法に利用される医療器 具である。枝分かれする血管にダメージを与えることなく目 的の血管部位へワイヤー先端を移動させるために，ガイドワ イヤー先端は低い剛性と大きな弾性歪久量が要求されると共 に，中間から手元部にかけては医者がワイヤーにかける突き 出し力に負壮ない腰の強さや良好なトルク伝達性(すなわち 高(㴊性)が要求される。なお，医療用ガイドワイヤーにつ いては, 文献 (28) に解説されているように, 現在使用され ている材料としては，主にステンレスと $\mathrm{Ni}-\mathrm{Ti}$ 基合金が挙 げられる。しかし，これら既存材料では，ワイヤー先端部々 手元部に要求される剛性の違いを同一の材料において満足さ せるのは困難である。

$\mathrm{Cu}-\mathrm{Al}-\mathrm{Mn}$ 基合金は， $\mathrm{Ni}-\mathrm{Ti}$ 基合金に匹敵する大きな超弾 性丕みを示すばかりでなく，ベイナイト変態により剛性を著 しく高めることができることからガイドワイヤーへの適用が 検討された。図 15 は試作された太さ $\phi 0.5 \mathrm{~mm}$ ，長さ 1500 mmのガイドワイヤーである。ここで，このガイドワイヤー 

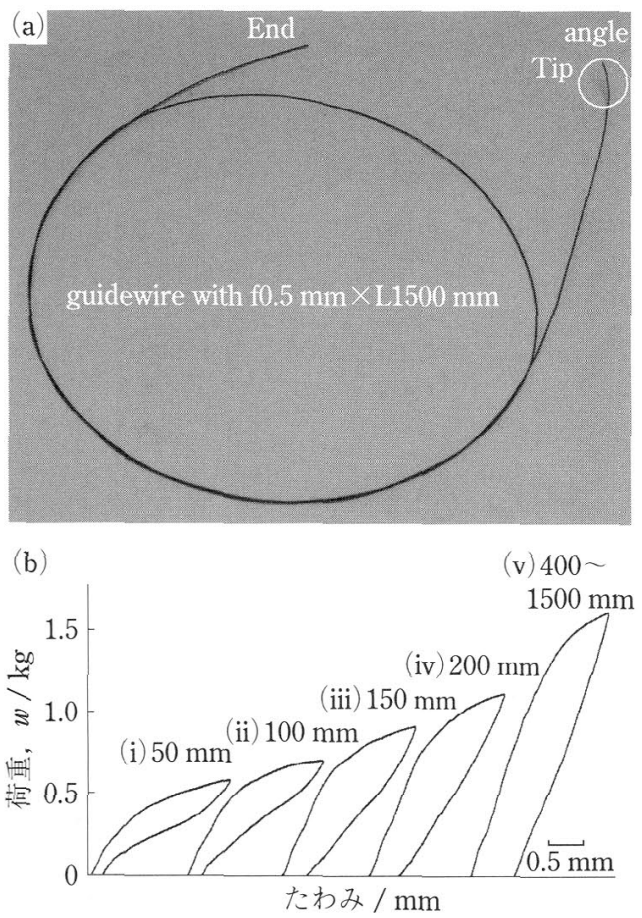

図15 試作された特性傾斜ガイドワイヤーの概観，お よび(b) その幾つかの部分に抢ける曲げ荷重一た わ久特性 ${ }^{(29)}$.

は，温度傾斜をつけた特殊な電気炉により熱処理を行い場所 により特性の変化を付与している. 先端から様々な距離に位 置する部分の 3 点曲げ試験により得られた荷重一たわ及線図 を図15(b)に示している，先端部では典型的な超弾性曲線を 示しているが, 先端から $150 \mathrm{~mm}$ 位からは降伏応力が上昇 すると同時に超弾性特性が消隇する様子が同われる。このガ イドワイヤーは優れた押し出し性とトルク伝達性を有するこ とも確認された。図16は，図中に示すように2巻きしたウ レタン性のチューブ中にワイヤーを入れ，手元部を回転させ たときに先端部がどのように追従するかを評価した結果を示 している.手元部の回転に先端部が理想的に追従する場合 は，プロットは中央の一点鎖線で示した直線に乗る. 図から わかるように， Ni-Ti 基合金では十分な追従が困難である

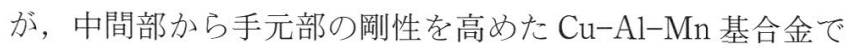
は非常に良好な特性が得られた ${ }^{(29)}$ 。このように $\mathrm{Cu}-\mathrm{Al}-\mathrm{Mn}$ 基合金は，単に $\mathrm{Ni}-\mathrm{Ti}$ と同程度の特性を持つに留まらず, ベイナイト变態を利用することにより $\mathrm{Ni}-\mathrm{Ti}$ 基合金には無 い優れた特徵を持つことがわかる.

\section{(2) マイクロチューブの試作}

外形が $1.0 \mathrm{~mm}$ を切る形状記憶合金チューブは， $\mathrm{Ni}-\mathrm{Ti}$ 基 合金においても実用されているが，加工に多くの手間がかか るためコストの点が問題である。 $\mathrm{Cu}-\mathrm{Al}-\mathrm{Mn}$ 基合金はその 高い加工性から，Ni-Tiに比して遥かに容易にマイクロチュ ーブを作製することが可能である。図 17 (a) は, 外形 $\phi 1.0$ $\mathrm{mm} \times$ 内径 $\phi 0.85 \mathrm{~mm}$ 打よび外形 $\phi 0.6 \mathrm{~mm} \times$ 内径 $\phi 0.5 \mathrm{~mm}$

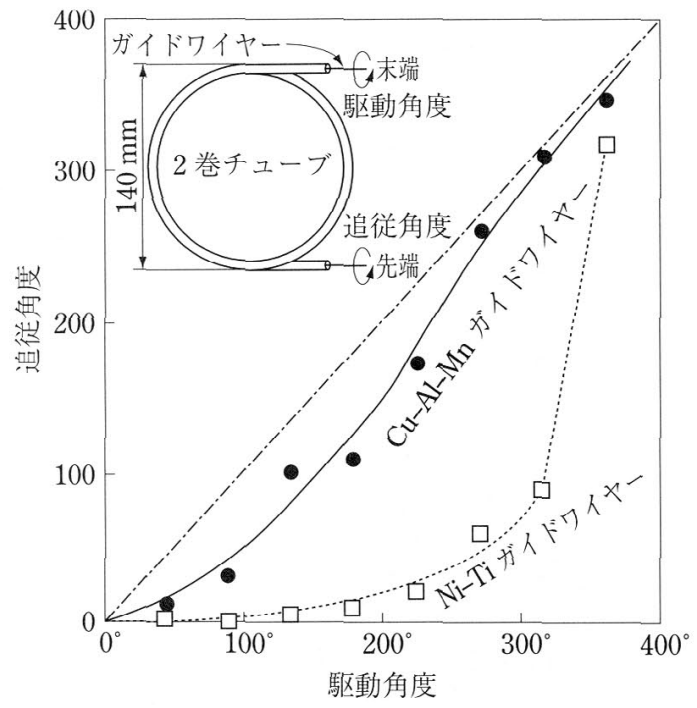

図16 $\mathrm{Cu}-\mathrm{Al}-\mathrm{Mn}$ 基抢よび $\mathrm{Ni}-\mathrm{Ti}$ ガイドワイヤーのト ルク追従性試験の方法と結果。ここで, 評価に は内径 $3 \mathrm{~mm}$ のテフロン製チューブを利用した。

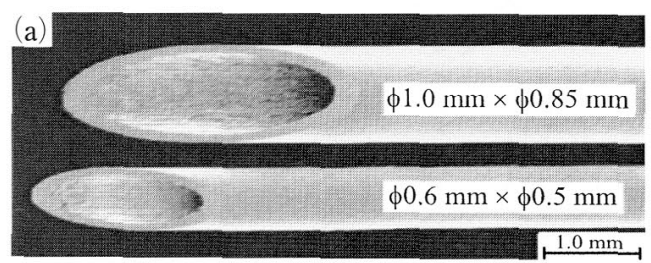

(b) 引張試験

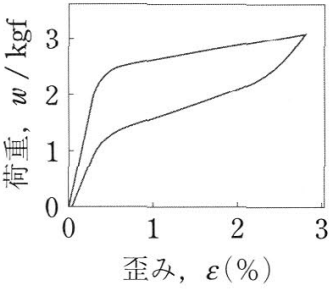

(c) 曲げ試験

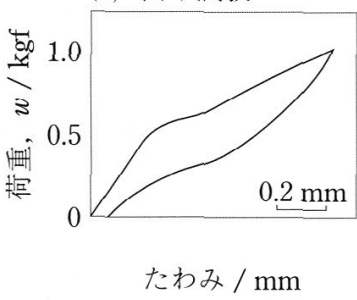

図 17 試作された外形 $1.0 \mathrm{~mm} \times$ 内径 $0.85 \mathrm{~mm}$ 打よび 外形 $0.6 \mathrm{~mm} \times$ 内径 $0.5 \mathrm{~mm}$ チューブの (a) 概観 および(b)引張特性, (c) 曲げ特性.

のチューブの SEM 像である. 図17(b)および(c)は, それぞ れ引張抢よび曲げ試験により得られた荷重一歪久およで荷重一 たわ久線図であるが，適正な加工熱処理で結晶粒径を制御す ることにより，良好な超弾性特性を得ることができる。千ュ 一ブは医療用カテーテルとしての用途が考えられるが，本合 金は高い制振特性も有するので制振性を具備したパイプとい う興味ある応用も考えられ，医療用に留まらず産業分野での 応用も期待される。

\section{7. 終わりに}

$\mathrm{Cu}-\mathrm{A} 1-\mathrm{Mn}$ 合金が他の $\mathrm{Cu}$ 系形状記憶合金と異なる点を 1 つだけ挙げるとすれば，それは高い加工性であると言えよ う。“加工性” は，材料の持つ多くの特性の中のほんの 1 つ 
表 $1 \mathrm{Cu}-\mathrm{Al}-\mathrm{Mn}$-based, $\mathrm{Ni}-\mathrm{Ti}, \mathrm{Cu}-\mathrm{Zn}-\mathrm{Al}$ and $\mathrm{Cu}-\mathrm{Al}-\mathrm{Ni}$ 形状記憶合金の特性比較(3)-(11)(30)-(33).

\begin{tabular}{lccccccc}
\hline \hline & $\begin{array}{c}\text { 変態温度 } \\
\left({ }^{\circ} \mathrm{C}\right)\end{array}$ & $\begin{array}{c}\text { 冷間圧延率 } \\
(\%)\end{array}$ & $\begin{array}{c}\text { SE } \\
(\%)\end{array}$ & $\begin{array}{c}\text { OWME } \\
(\%)\end{array}$ & $\begin{array}{c}\text { TWME } \\
(\%)\end{array}$ & $\tan \phi^{* * *}$ & 参考文献 \\
\hline $\mathrm{Cu}-\mathrm{Al}-\mathrm{Mn}$-based & -200 to 150 & $>60$ & 7.5 & $\sim 10^{*}$ & $\sim 2.2(3)^{* *}$ & 0.37 & $(3)-(11)$ \\
$\mathrm{Ni}-\mathrm{Ti}$ & -40 to 100 & $\sim 30$ & 8 & 8 & 5 & 0.1 & $(30)-(33)$ \\
$\mathrm{Cu}-\mathrm{Zn}-\mathrm{Al}$ & -200 to 120 & $\sim 30$ & 2 & 5 & 2 & 0.12 & $(30)-(33)$ \\
$\mathrm{Cu}-\mathrm{Al}-\mathrm{Ni}$ & -200 to 170 & $\sim 10$ & 2 & 5 & 2 & - & $(30)-(33)$ \\
\hline
\end{tabular}

* 曲げ試験により得られた 1 万向形状記憶表面歪みを示す.

** 引張変形を与えることにより誘起された 2 万向形状記憶歪みを示す. 尚, 括弧内の数值は曲げ変形を与えることにより誘起された 2 方向形状記憶表面歪みを示す。

*** 本研究において, 粘弾性測定装置を用いて得られた数值であり, $\tan \phi$ vs. 温度曲線のピークの值を示す.

にしかすぎないが，製造コストの低減だけでなく，結晶粒径 や集合組織の制御が可能となり，ひいては形状記憶特性の飛 躍的な向上が導き出された. 形状記憶特性が粒径や集合組織 などの組織因子によって，これ程大きく影響を受ける事は当 初予想されなかったが, この高加工性によってその定量的効 果を評価する事が出来た．表 1 に, $\mathrm{Cu}-\mathrm{Al}-\mathrm{Mn}$ 基合金と $\mathrm{Ni}-$ $\mathrm{Ti}$ および他の $\mathrm{Cu}$ 系形状記憶合金との間の諸特性に関する 比較を示す(3)-(11),(30)-(33)。本稿では割愛したが, $\mathrm{Cu}-\mathrm{Al}-\mathrm{Mn}$ 基合金は可逆形状記憶効果や制振特性においても優れた性質 を有していることを強調したい。

最後に，本 $\mathrm{Cu}-\mathrm{Al}-\mathrm{Mn}$ 合金が真の実用に至る為には，疲 労強度や耐熱性向上など具体的に改善すべき材料学的問題は 少なくない。また，いわゆる新素材に共通した悩みとして， その材料に適した用途の開発が不可欠である. 読者からのご 指導，ご助言を頂ければ幸いである.

本研究を遂行するに当たり多大なご協力を頂いた, 東北大 学大学院, 佐藤直也氏, 高橋 心氏, 王継傑氏に心から御礼 申し上げます。 また, 本研究は, 文部科学省, 科学研究費補 助金により遂行された.

\section{文献}

(1) S. Miyazaki and K. Otsuka: ISIJ. Int., 29(1989), 353-377.

(2) T. Tadaki : Shape memory materials, ed. by K. Otsuka and C. M. Wayman, Cambridge University Press, Cambridge, United Kingdom, (1998), 97-116.

( 3 ) R. Kainuma, S. Takahashi and K. Ishida: J. Phys. IV., 5(C8) (1995), 961-966.

(4) R. Kainuma, S. Takahashi and K. Ishida: Metall. Mater. Trans. A, 27A(1996), 2187-2195.

(5) Y. Sutou, R. Kainuma and K. Ishida: Mater. Sci. Eng. A, 273$\mathbf{2 7 5}$ (1999), 375-379.

(6) T. Omori, Y. Sutou, T. Okamoto, R. Kainuma and K. Ishida: Trans. Mater. Res. Soc. Jpn., 26(2001), 227-230.

( 7 ) Y. Sutou, T. Omori, R. Kainuma, N. Ono and K. Ishida: Metall. Mater. Trans. A, 33A (2002), 2817-2824.

( 8 ) T. Omori, J. J. Wang, Y. Sutou, R. Kainuma and K. Ishida: Mater. Trans., 43(2002), 1676-1683.

( 9 ) Y. Sutou, T. Omori, J. J. Wang, R. Kainuma and K. Ishida: J. Phys. IV.(ICOMAT'02), in press.

(10) T. Omori, Y. Sutou, J. J. Wang, R. Kainuma and K. Ishida: J. Phys. IV. (ICOMAT'02), in press.
（11）大森俊洋, 肥田直樹, 須藤祐司, 鈴木秀和, 脇田将見, 貝沼 亮介，石田清仁：銅と銅合金，42(2003)，198-201.

(12) R. Kainuma, N. Satoh, X. J. Liu, I. Ohnuma and K. Ishida: J. Alloys Comp., 266(1998), 191-200.

(13) C. Lopez del Castillo, B. G. Mellor, M. L. Blazquez and C. Gomez: Scr. Metall., 21(1987), 1711-1716.

(14) S. J. L. Kang, M. Stasi and P. Azou: Mem. Etud. Sci. Rev. Metall., 79(1982), 229-234.

(15) K. Matsushita, T. Okamoto and T. Okamoto: J. Mater. Sci., 20(1985), 689-699.

(16) J. M. Guilemany and F. Peregrin: J. Mater. Sci., 27(1992), 863-868.

(17) Dvorak and E. B. Hawbolt: Metall. Trans. A, 6A(1975), 9599.

(18) G. N. Sure and L. C. Brown: Metall. Trans. A, 15 (1984), 16131621.

(19) H. Inoue, N. Miwa and N. Inakazu: Acta Mater., 44(1996), 4825-4834.

(20) L. Zhao, P. F. Willemse, J. H. Mulder, J. Beyer and W. Wei: Scr. Mater., 39(1998), 1317-1323.

(21) S. Eucken and J. Hhirsch: Mater. Sci. Forum, 56-58(1990), 487-492.

(22) P. Donner and S. Eucken: Mater. Sci. Forum, 56-58(1990), 723-728.

(23) S. Miyazaki, V. H. No, K. Kitamura, A. Khantachawana and H. Hosoda: Int. J. Plasticity, 16 (2000), 1135-1154.

(24) 須藤祐司：博士論文, 東北大学, (2001).

(25) N. Ono, A. Sato and H. Ohta: Mater. Trans., JIM, 30(1989), 756-764.

(26) K. Takezawa and S. Sato: Metall. Trans. A, 21(1990), 15411545.

(27) K. Takezawa and S. Sato: Mater. Trans. JIM, 33(1992), 102109.

（28）金子 隆：金属系バイオマテリアルの基礎と応用 角田 方衛, 筏 義人, 立石哲也編, 株式会社アイピーシ, (2000), 485-499.

(29) Y. Sutou, T. Omori, A. Furukawa, Y. Takahashi, R. Kainuma, K. Yamauchi, S. Yamashita and K. Ishida: J. Bio. Mater. Res. Part B (Applied Biomaterials), in press.

(30) T. Suzuki: Shape memory materials, ed. by K. Otsuka and C. M. Wayman, Cambridge University Press, Cambridge, United Kingdom, (1998), 133-148.

(31) J. Van Humbeeck and R. Stalmans: Shape memory materials, ed. by K. Otsuka and C. M. Wayman, Cambridge University Press, Cambridge, United Kingdom, (1998), 149-183.

(32) J. Van Humbeeck and L. Delaey: The martensitic transformation in science and technology, ed. by E. Hornbogen and N. Jost, DGM, Informationsgesellschaft, (1989), 15-25.

(33) P. Tautzenberger: The martensitic transformation in science and technology, ed. by E. Hornbogen and N. Jost, DGM, Informationsgesellschaft, (1989), 213-218. 